\title{
Agronomic Approaches to Improve Cereal Production under Abiotic Stress
}

\author{
K. R. Siddagangamma* \\ Department of Agronomy, College of Agriculture, University of Agricultural Sciences, \\ Raichur-584104, Karnataka, India \\ *Corresponding author
}

\section{Keywords}

Abiotic stress,

Drought, Heat,

Agronomic

approaches

\section{Article Info}

Accepted:

20 January 2020

Available Online:

10 February 2020
Agriculture sector is highly sensitive to climate change due to its heavy dependence on climate and weather. Climate change is ever lasting process as the temperature keeps on increasing day by day. This largely affects our agriculture production in negative way. Due to this, abiotic stresses are comes into play a major role in agriculture. Under abiotic stresses the combined effect of both heat and drought stress on yield of many crops is stronger than the effect of each stress alone. According to estimates, on an average $50 \%$ yield losses in agricultural crops are due to different abiotic stresses. The expected changes in the climate could strongly affect the agriculture production worldwide. Heat and Moisture stresses are the present day hot topics in the world as it throws great challenges before the scientific world by adversely affecting the crop plants and their yield. Hence abiotic stress management through the use of agronomic practices can reduce the negative impact and increase the crop potential to withstand stresses and ultimately increased crop yield.

\section{Introduction}

Agriculture sector is highly sensitive to climate change due to its heavy dependence on climate and weather. India is still agrarian country and 70 per cent of population depending on agriculture for their livelihood. Global yields of many crops have already shown reduction of 10 to $20 \%$ since 1980 in lower latitudes, relative to what they would have been in the absence of climate change due to changing climates. Continuing warming of the atmosphere, reduction in rainfall in areas of rainfed crop production, increase in pests due to warming and other climatechange-related impacts, pose a real and serious threat to global, national and local food security. Suitable agronomic practice adaptation to climate change, resources impacts should be one of the most pressing needs to maintain the sustainability. 
What does stress mean to an agriculturalist?

Stress in biological terms means deviation in the normal physiology, development and function of plants which can be injurious and can inflict irreversible damage to the plant system. The type of stress that crop plants suffer from can be broadly grouped as temperature variation at crucial stages. There are several sticky abiotic parameters revolving around temperature e.g., frost damage and evaporation stress.

Agricultural terms, Stress is defined as a phenomenon that limits crop productivity or destroys biomass.

\section{Abiotic stress}

Abiotic stress management is one of the most important challenges facing agriculture. Abiotic stress can persistently limit choice of crops and agricultural production over large areas and extreme events can lead to total crop failures. Abiotic stresses adversely affect the livelihoods of individual farmers and their families as well as national economies and food security.

"The negative impact of non-living factors on living organisms in a specific environment" Abiotic stress factors or stressors are naturally occurring often intangible factors.

Major abiotic stresses:

\section{Moisture stress}

(a) Water deficit (Drought) (b) Excessive moisture stress (water logging)

\section{Temperature stress}

a. High temperature stress (b) Low or chilling temperature stress

\section{Water stress / Drought stress}

Drought stress is a condition of moisture deficit sufficient to have an adverse effect on vegetation, animal and man over a sizeable area.

Plants experience water stress either when the water supply to their roots becomes limiting or when the transpiration rate becomes intense.

Since drought is defined by deviation from the normal rainfall, it can happen in all rainfall regions. It also occurs in high rainfall area but severity or frequency may vary.

Assessment and management of drought is complex due to its gradual appearance and long lasting impact or recoveries.

Prolonged dry spells during the critical growth stages especially during flowering to seed filling stage (terminal drought), heavily reduce the yield of the crop.

Agricultural drought occurs when both rainfall and soil moisture are inadequate during growing season to support crop.

The impact of drought on agriculture is due to a deficit of moisture in the soil, when the moisture in the soil is no longer sufficient to meet the needs of growing crops.

\section{Effects of drought stress on crops}

Reduced seed germination and seedling development

Poor vegetative growth

Reproductive growth is severely affected

Plant height and leaf area reduced

Reduced photosynthesis

Significantly reduction in the total dry matter

Sabetfar et al., (2013) showed that the cultivar Hashmi was more sensitive to drought stress in the mid tillering and panicle initiation than 
the 50 per cent flowering stage. Highest performance was related to control treatment with $3710 \mathrm{kgha}^{-1}$ and lowest performance was related to the treatment with severe stress in middle tillering phase with $2087 \mathrm{~kg} \mathrm{ha}^{-1}$. Here decrease performance of yield depends not only on moisture stress severity and duration, but also to its occurrence time in different growth phases.

\section{Heat stress}

Among the ever changing components of the environment, the constantly rising ambient temperature is considered one of the most detrimental stresses.

The global air temperature is predicted to rise by $0.2{ }^{\circ} \mathrm{C}$ per decade, which will lead to temperatures $1.8-4.0{ }^{\circ} \mathrm{C}$ higher than the current level. This prediction is creating apprehension among scientists, as heat stress has known effects on the life processes of organisms, acting directly or through the modification of surrounding environmental components. Plants, in particular, as sessile organisms, cannot move to more favourable environments; consequently, plant growth and developmental processes are substantially affected, often lethally, by high temperature (HT) stress.

Heat stress is often defined as the "rise in temperature beyond a threshold level for a period of time sufficient to cause irreversible damage to plant growth and development".

Heat stress affects plant growth throughout its ontogeny, though heat-threshold level varies considerably at different developmental stages.

In general, $10-15^{\circ} \mathrm{C}$ above ambient, is considered heat shock or heat stress.

Factors determining severity of abiotic stresses

Abiotic stresses are integral part of any agro eco-system, it affects crop plant in variety of ways. However, the severity and impact varies from location to location because several factors determine the severity and impact of abiotic stresses like Soil type, temperature, relative humidity, organic matter in the soil, local vegetation, precipitation etc.

Agronomic practices to mitigate abiotic stress (Drought and Heat)

Major strategies to mitigate stress includes

Selection of suitable genotypes

Time of sowing and Method of planting

Seed priming and Seed hardening

Tillage practices / Land Preparation Practice

In-situ moisture conservation measure

Use of growth regulators and Anti-transpirants

Application of Mulches

Application of Hydrogels

\section{Selection of suitable genotypes}

Tolerant crop varieties with consistently higher yields under deficit rainfall and high temperature are very important to overcome abiotic stress.

Identifying stress tolerant cultivars for different agro-ecologies of the country appears to be the major challenge to increase the productivity in order to meet the demand of more food.

\section{Time of sowing and Method of planting}

Sowing time is one of the most important management factors involved in obtaining higher yield.

Time of sowing is one of the most important non-monetary inputs for optimizing the growth and yield of the crop.

Selecting optimum planting time, avoids high temperature stress during anthesis and grain filling. 
High temperature at that time shortens the season and reduces yield.

By Adjusting sowing time, crop escapes to hot and desiccating wind during grain filling period.

The performance of crop varies with different dates of planting.

Singh et al., (2011) found that crop sown on 25 November produced significantly higher yield (44.7 $\mathrm{q} \mathrm{ha}^{-1}$ ) as compared to crop sown on 10 December $\left(30.0 \mathrm{q} \mathrm{ha}^{-1}\right)$. The grain yield of wheat under early sown crop could be attributed to better basic infrastructural frame work of plants in early sowing. Timely sowing of wheat crop generally gives higher yield as compared to late sown crop. Late-sown wheat crop faces high temperature stress during ripening phase. Late planting reduces the tillering period and hot weather during critical period of grain filling lead to forced maturity thereby reduces the grain yield.

The optimum time of sowing for wheat crop in India is first fortnight of November. The delay in sowing of crop is mainly because of late harvest of paddy crop, delay in field operations, climate changes etc. which results in sowing of crop up to first fortnight of January. Crop sown in mid November shows better growth and yield parameter than the rest of sowing dates which is followed by late November sowing (Mukherjee, 2012).

Among three microclimatic regimes, highest yield (4066 kg/ha) was recorded in rice transplanted on 26 June which also received highest accumulated rainfall of $1197 \mathrm{~mm}$. Maximum temperature during the crop growing season was within cardinal range of temperature $\left(27.6-35.1^{\circ} \mathrm{C}\right)$ for kharif rice. However, minimum temperature was below $15^{\circ} \mathrm{C}$ during reproductive stage of late transplanted (late July) crop which might have affected crop yield due to spikelet sterility. Reduction in grain yield with each delay in sowing with respect to 26 June was observed due to reduction in rainfall and temperature during reproductive period (Anon., 2018).

\section{Effect of methods of planting}

The selection of suitable method of planting plays an important role in the placement of seed at proper depth, which ensures better emergence and subsequent crop growth.

Sridhara et al., (2011) reported that genotype BI-43 recorded significantly more root length $(25.1 \mathrm{~cm})$ with more root volume $(62.0 \mathrm{cc})$. Rasi, a check variety performed next to BI-43, while the performance of BI-27 was not superior in any root character than check variety. Development of root traits is dependent on gene factor and also the environment in which crop is grown. Mean grain yield of $49.0 \mathrm{qha}^{-1}$ was recorded in BI-43 and was significantly superior to Rasi and BI27 and lowest yield was recorded by BI-27 (43.1 q ha ${ }^{-1}$ ). Higher yield in BI-43 was due to more number of tillers which inturn leads to more panicles plant ${ }^{-1}$ and also better survival of tillers. Higher root traits in BI-43 which in turn helps in higher nutrient uptake resulted in higher yield. Direct seeding recorded significantly higher root volume $(67.66 \mathrm{cc})$ and root length $(25.9 \mathrm{~cm})$ compared to other methods. Higher root traits under direct seeding were due to better aeration and less degeneration of roots. Higher yield under direct seeding was mainly due to less time taken for new root development and early initiation and development of tillers leads to higher productive tillers.

\section{Seed priming and Seed hardening}

\section{Seed priming}

Pretreatment of seeds by various methods 
(water, chemicals like $\mathrm{KNO}_{3}$ ) in order to improve seed germination rate, percentage germination, and improve uniformity of seedling emergence by controlling the water available in the seed.

Seed priming is a controlled hydration technique in which seeds are soaked in water or low osmotic potential solution to a point where germination related metabolic activities begin in the seeds.

Seed hardening is the physiological preconditioning of the seeds by hydration to withstand drought under rainfed condition.

Seed hardening is a process or treatment by which plants growing from the hardened seeds are capable of withstanding soil moisture stress

Seeds are soaked in $2 \%$ potassium dihydrogen phosphate solution for $10 \mathrm{hrs}$ and then dried back to original moisture

Singh et al., (2011) reported that february 20 planted crop which was highest yield among all the three planting dates. Although this was statistically at par with February 10 planting but it was $61.9 \%$ higher than March 2 planted crop. With foliar application treatments, $1 \%$ potassium nitrate at tassel initiation (TI) stage resulted in significantly higher all yield attributes except number of cobs per plant that was recorded as not significant but grain yield was significantly higher with foliar application of $1 \%$ potassium nitrate at TI stage $(5.73 \mathrm{t} / \mathrm{ha})$ which was $28.8 \%, 20.6 \%$ and $15.5 \%$ higher than that obtained with control (no spray), water spray at TI and water spray at TI + another spray after one week. But it was statistically at par with foliar application of $1 \%$ potassium nitrate at $\mathrm{TI}+$ another spray after one week, $2 \%$ potassium nitrate at $\mathrm{TI}$ and $2 \%$ potassium nitrate at $\mathrm{TI}+$ another spray after one week with application of $1 \%$ potassium nitrate at $\mathrm{TI}$.
Bhuvanaswri et al., (2016) revealed that early sown aerobic rice on $12^{\text {th }}$ September hardended with one per cent $\mathrm{KCl}$ and water recorded higher grain yield under water stress condition over other treatments. Crop raised on $12^{\text {th }}$ September resulted in increased grain yield of 58 per cent higher over the crop raised on October $4^{\text {th }}$. The crops that were raised on $4^{\text {th }}$ October was exposed to higher $\mathrm{RH}$ (93.78\%) coupled with low temperature of $28.12{ }^{\circ} \mathrm{C}$ which induces the spikelet sterility and increased the number of ill-filled grains.

\section{Land preparation practice}

Farmers believed that their fields are leveled and needed no further leveling. But the digital elevation survey sheet of a field shows that most of the fields are not adequately leveled and requires further precision land leveling. The enhancement of water use efficiency and farm productivity at field level is one of the best options to readdress the problem of declining water level in the state. The planner and policy makers are properly informed and motivated to develop strategies and programs for efficient utilization of available water resources.

\section{Laser land leveling and zero tillage are the two important water saving technology}

Land leveling of farmer's field is an important process in the preparation of land. It enables efficient utilization of scarce water resources through elimination of unnecessary depression and elevated contours

\section{Laser land leveling (Water-smart technologies)}

The advanced method to level the field is to use laser-guided leveling equipment.

Laser leveling is a process of smoothening the land surface $(2 \mathrm{~cm})$ from its average elevation. 
Precision land leveling involve altering the field in such a way as to create a constant slope of 0 to $2 \%$.

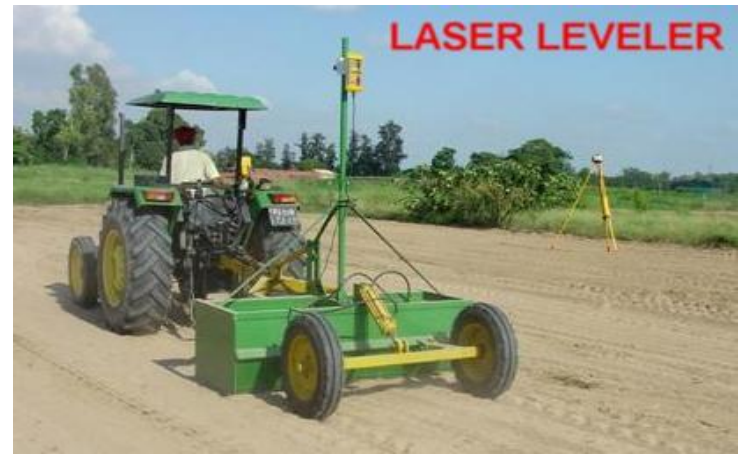

\section{Benefits of laser land leveling}

Reduces the time and water required to irrigate the field

More uniform distribution of water in the field More uniform moisture environment for crops More uniform germination and growth of crops

Improves application and distribution efficiency of irrigation water

Increases water use efficiency

Reduces weed problems by even water distribution

increases opportunity to use direct seeding increases yield

Naresh et al., (2014) revealed that laser leveled field exhibited the higher water use efficiency and yield in rice and wheat compared to traditional method of leveling and no leveling. Land leveling of farmer's field is an important process in the preparation of land. It enables efficient utilization of scarce water resources through elimination of unnecessary depression and elevated contours.

\section{Zero tillage (Water/Energy-smart technologies)}

Zero-tillage is gaining popularity amongst the farmers in the Indo-Gangetic Plains for establishing wheat and to some extent in rice and other crops.
By using this technology, the rice-wheat farmers can undertake direct drilling of wheat soon after harvesting of rice without any preparatory tillage, so that wheat crop heads and fills grain before the onset of premonsoon hot weather.

This involves sowing with a speciallydesigned zero-till seed-cum-fertilizer drill/planter, which has inverted ' $\mathrm{T}$ '-type furrow opener to make a narrow slit in the soil for placing seed and fertilizer.

\section{The main advantages include}

Saves irrigation water up to $10-15 \%$ during first irrigation.

Two days early and uniform germination and better plant stand than traditional.

No crust formation after rains, hence no effect of rains on germination.

Improvement in crop yield.

Improvement in soil structure and fertility.

No lodging of crops at the time of maturity in case of heavy rains.

Guptha and Ashok (2007) conducted trail at different district of Punjab and Haryana and they reported that higher wheat yield observed with zero-tillage. This is largely due to the time saved in land preparation that enabled a timelier planting of wheat crop. It has been reported from the simulation study that planting time of wheat regulates yield, governed by the climatic parameters, mainly through temperature and delayed planting results in significant losses in yield.

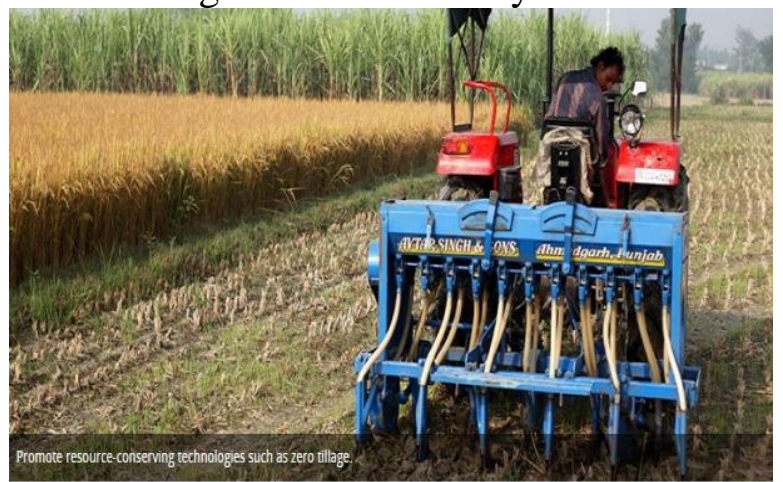




\section{Zero-till seed-cum-fertilizer drill/planter}

Chhetri et al., (2016) revealed that among the Climate Smart Agriculture (CSA) practices and technologies including use of improved crop varieties, laser land leveling, zero tillage. Results showed that farmers can increase net return of Rs. 15,712 $\mathrm{ha}^{-1} \mathrm{yr}^{-1}$ with improved crop varieties, Rs. $8,119 \mathrm{ha}^{-1} \mathrm{yr}^{-1}$ with laser leveling and Rs. 6,951 $\mathrm{ha}^{-1} \mathrm{yr}^{-1}$ with zero tillage in rice-wheat system. Results also showed that the combination of improved seeds with zero tillage and laser land leveling technologies can further improve crop yields as well as net returns. The econometric analysis indicates that implementations of CSA practices and technologies in smallholder farms in the IGP of India have significant impacts on change in total production costs and yield in rice-wheat system.

Sutaliya et al., (2016) showed that different CSAPs used in various scenarios had significant effect on crop productivity and profitability. The best management practices of laser levelled field adapted variety and precision nutrient management under zero tillage, improved up to $40 \%$ grain yield and $65 \%$ net return of wheat as compared farmers practice.

\section{In-situ moisture conservation measure}

Productivity of rainfed crops has failed to attain a plateau due to lack of efficient conservation and utilization of the natural resources like soil and water and poor management practices to exploit the conserved soil moisture. The most important constraint for low yields is the inadequate supply of soil moisture during the Rabi season. So, in situ moisture conservation practices known to aid in increased retention of rain water and its conservation in the soil.

Sakthivel et al., (2003) reported that tied ridges and ridges and furrows recorded higher moisture use efficiency as the result of higher and uniform availability of soil moisture throughout the crop growth, which encouraged both vegetative and reproductive growth of maize crop.

Girijesh et al., (2006) reported that highest grain yield of $4145 \mathrm{~kg} / \mathrm{ha}$ was realized in the treatments receiving two irrigations each at silking and grain filling stage. Closely followed by the treatments that received one irrigation at grain development stage (3964 $\mathrm{kg} / \mathrm{ha}$ ). The treatment which, received one irrigation at silking recorded the grain yield of $3794 \mathrm{~kg} / \mathrm{ha}$. Since, these stages are critical for water supply, protective irrigation at these stages probably, helped the crop. Among other practices, mulching was significantly superior to control with 17.8 per cent higher yield owing to growth and yield components. Thus, it can be inferred that under delayed sowing situation, providing one or two life saving irrigations at silking and grain development stages are most critical from the point of view in maize otherwise at least mulching needs to be followed.

Sudhakar et al., (2016) revealed that compartmental bunding to retain and impound the incidental rainfall during kharif was found to be significantly superior among the in-situ moisture conservation practices in terms of grain yield $\left(3.36 \mathrm{t} \mathrm{ha}^{-1}\right)$, fodder yield $(6.82 \mathrm{t}$ $\mathrm{ha}^{-1}$ ), gross returns (Rs. $91560 \mathrm{ha}^{-1}$ ), net returns (Rs. $75293 \mathrm{ha}^{-1}$ ) compared to other treatments. This could be ascribed due to the reduced surface runoff, greater soil water retention and also due to increased water holding capacity of the soil.

Use of Growth regulators, mulches and anti-transpirants

Antitranspirants are chemical compounds whose role is to train plants by gradually hardening them to stress as a method of 
reducing the impact of drought. There are different types of anti-transpirants: film forming which stops almost all transpiration; stomatic, which only affects the stomata; reflecting materials. Reducing transpiration can play a useful role in this respect by preventing the excessive loss of water to the atmosphere via stomata.

\section{Mulching}

Mulch are used for various reasons but water conservation and erosion control are most important for dry land agriculture

Mulch in standing crop helps in conservation and carryover of soil moisture for timely sowing of crop.

Incorporate plant residues into soil resulting into better moisture storage by increasing organic matter content of soil.

Singh et al., (2011) showed that one foliar spray of $\mathrm{KNO}_{3}(1 \%)$ during anthesis was at par in grain yield than those obtained with conventional tillage without mulching + two foliar spray of $\mathrm{KNO}_{3}(1 \%)$ during anthesis produced the statistically similar grain yield. However, one foliar spray of $\mathrm{KNO}_{3}(1 \%)$ during anthesis gave the highest grain yield followed by two foliar spray of $\mathrm{KNO}_{3}(1 \%)$ during anthesis as compared to one extra irrigation during post anthesis and recommended irrigation.

Rao et al., (2012) reported that drought stress was induced by withholding water after five days of Salicylic acid and L-Tryptophan application. Significantly higher relative water content and potassium content were found in plants treated with 100 ppm Salicylic acid and 15 ppm L-Tryptophan compared with other treatments and control plants. Results suggest that foliar application of Salicylic acid and LTryptophan can play a role to reduce the effect of drought in maize.

\section{Application of Hydrogels}

Hydrogel is most popularly used to reduce water runoff and increase infiltration rates in field agriculture, in addition to increasing water holding capacity for agricultural applications. The use of hydrogels led to the significant decrease in the number of irrigations, especially for the soils with large scale texture.

Water saving technology through hydrogel is very useful in achieving higher productivity and profitability of maize. Hydrogel (Super absorbent polymer) is a water retaining, biodegradable, amorphous polymer which can absorb and retain water at least 400 times of its original weight and make at least 95 per cent of stored water available for crop absorption. When it is mixed with the soil, it forms an amorphous gelatinous mass on hydration and is capable for retaining it for longer period in soil and releasing water slowly as per crop root demand.

"Hydrogel is a hydrophilic polymer having high water holding capacity and can provide water to crops during moisture stress".

Table.1 Yield loss in major cereals crops

\begin{tabular}{|c|c|c|}
\hline Crop & Abiotic stress & $\begin{array}{c}\text { Yield } \\
\text { reduction }\end{array}$ \\
\hline \multirow{2}{*}{ Rice } & Drought & $53-92 \%$ \\
\cline { 2 - 3 } & Heat & $50 \%$ \\
\hline \multirow{2}{*}{ Maize } & Drought & $63-87 \%$ \\
\cline { 2 - 3 } & Heat & $42 \%$ \\
\hline \multirow{2}{*}{ Wheat } & Drought & $57 \%$ \\
\cline { 2 - 3 } & Heat & $31 \%$ \\
\hline
\end{tabular}


Table.2 Effects of high temperature stress in cereals

\begin{tabular}{|c|c|c|l|}
\hline Crops & Heat treatment & Growth stage & \multicolumn{1}{c|}{ Major effects } \\
\hline Rice & $\begin{array}{c}\text { Above } \\
33^{\circ} \mathrm{C}, 10 \text { days } \\
37 / 28^{\circ} \mathrm{C} \\
(\text { day } / \text { night }), \\
20 \text { days }\end{array}$ & $\begin{array}{c}\text { Heading stage } \\
\text { Wrain filling } \\
\text { and } \\
\text { maturity stage }\end{array}$ & $\begin{array}{l}\text { Reduced the rates of pollen and spikelet } \\
\text { fertility }\end{array}$ \\
\hline $\begin{array}{c}\text { Shortened duration of grain filling and } \\
\text { maturity, decreases in kernel weight and } \\
\text { yield. }\end{array}$ \\
\hline Maize & $\begin{array}{c}\text { Reproductive } \\
\text { stage }\end{array}$ & $\begin{array}{l}\text { Reduced ear expansion and photosynthate } \\
\text { supply. }\end{array}$ \\
\hline
\end{tabular}

Key characteristics of agricultural hydrogels

Agricultural hydrogels are natural polymers containing a cellulose backbone.

They can also perform well at high temperatures $\left(40-50^{\circ} \mathrm{c}\right)$ stress and hence are suitable for semi-arid and arid regions.

They can absorb a minimum of 400 times of their dry weight of pure water and gradually release it according to the needs of the crop plant.

Because of their neutral $\mathrm{pH}$, they do not affect nutrient availability, soil chemical composition, action of other agro chemicals, viz. fertilizers, herbicides, fungicides, insecticides, etc.

Huge potential for use in Agriculture as water economy aid in Dry-land agriculture, horticulture, floriculture and nursery raising

Hydrogels are found to improve the physical properties of soils

Aniket et al., (2016) obtained results from farmers field demonstration conducted by ICAR at different locations in Uttar Pradesh evidenced that soil application of hydrogel @ $5 \mathrm{~kg} / \mathrm{ha}$ along with three irrigations in different wheat varieties is able to produce grain yield equivalent to irrigating wheat crop with five times without hydrogel application.
It indicates that soil application of hydrogel can save two irrigations in wheat without reducing the grain yield.

Roy et al., (2019) reported that the grain yield of wheat varied between $224.4 \mathrm{~g} \mathrm{~m}^{-2}$ for with hydrogel (WH) plots whereas for without hydrogel (WHO) it was $148.3 \mathrm{~g} \mathrm{~m}^{-2}$. Hydrogel acts as a great soil conditioner and not only helps to increase the yield of wheat but also reduces the water requirement of crop by $38 \%$ to $40 \%$. Almost three to four irrigations can be saved for wheat crops under irrigated conditions while under rainfed conditions the water stress is minimized.

In conclusion, adoption of agronomic practices like selection of stress tolerant varieties, timely sowing, seed hardening, laser land levelling, zero tillage, in-situ moisture conservation practices and use of hydrogel can alleviate the adverse impact of drought and heat stress in cereals.

\section{References}

Aniket, K., Rajeew Kumar, Singh, V. P. and Pandey, D. S., 2016, Hydrogels: a boon for increasing agricultural productivity in water-stressed environment. Current Sci., 111(11): 1773-1779

Anonymous, 2018, Annu. Rep. on AICRP on Agrometeorology, ICAR-CRIDA - 201718, Santoshnagar, Hyderabad, pp. 128.

Bhuvanaswri, P., Narayanan, A. L., Mohan, R. and Sundaravarathan, S., 2016, Crop 
weather relationship of aerobic rice. $4^{\text {th }}$ Int. Agron. Cong. New Delhi, India, 1:5152.

Chhetri, A. K., Aryal, J. P., Sapkota, T. B. and Khurana, R., 2016, Economic benefits of climate smart agricultural practices to smallholder farmers in the Indo-Gangetic Plains of India. Current Sci., 110 (7): 1251- 1256.

Girijesh, G. K., Kumara Swamy, A. S., Dinesh Kumar, M., Nataraju, S. P., Vageesh, T. S. and Rajashekarappa, K. S., 2006, Response of maize (Zea mays L.) to constraint irrigation under late sown conditions. Karnataka J. Agric. Sci., 24(5): 633-635.

Gupta and Ashok, 2007, Effect of tillage practices on wheat yield. Int. J. Agric. Sci., 6(2): 485- 487.

Mukherjee, 2012, Effect of date of sowing on growth and yield attributing characters of wheat crop. African J. Agril .Res., 9(4): 473-478.

Naresh, R .K., Sing, S. P., Mishra, A. K., Tomar, S.S., Pradeep Kumar, 2014, Evaluation of the laser leveled land leveling technology on crop yield and water use in western Uttar Pradesh. African J. Agril. Res., 9(4): 473:478.

Rao, Nadeem Akbar, Zahoor Ahmad and Rehan Aslam, 2012, Effect of foliar application of salicylic acid and L tryptophan on relative water content and potassium content of maize crop under heat stress. American-Eurasian J. Agric. Environ. Sci., 13(3): 301-306.

Roy, T., Suresh Kumar, Lekh Chand, Kadam, D. M., Bankey Bihari, Shrimali, S. S., Rajesh, B., and Maurya, U. K., 2019, Impact of Pusa hydrogel application on yield and productivity of rainfed wheat in North West Himalayan region. Current Sci., 116(7): 1246- 1251.

Sabetfar, S., Ashouri, M., Amir, E. and Babazadeh, S., 2013, Effect of drought stress at different growth stages on yield and yield component of rice plant. Persian Gulf Crop Protec., 2(2): 14-18 14.

Sakthivel, N., Balasubramanian, S., Radhamani and Subbian, P., 2003, Effect of in situ moisture conservation practices and intercropping system on yield of rainfed maize in western zone of Tamil Nadu. Madras Agric. J., 90 (7): 411-415.

Singh, A., Singh, D., Kang, J. S. and Aggarwal, N., 2011, Management practices to mitigate the impact of high temperature on wheat: a review. IIOABJ-India, 2(7): $11-22$.

Sridhara, C, J., Ramachandrappa, B. K., Kumarswamy, A. S. and Gurumurthy, K. T., 2011, Effect of genotypes and method of establishment on root traits and yield of aerobic rice. Karnataka J. Agric. Sci., 24(2):129-132.

Sudhakar, C., Sudha Rani, C. and Mishra, J. S., 2016, Influence of in-situ moisture conservation practices on yield and economics of rainfed rabi sorghum under receding soil moisture conditions. $4^{\text {th }}$ Int. Agron. Cong. New Delhi, India, 1:288289.

Sutaliya, J. M., Deepak Bijarniya1, Jat, R. K. and Jat, M. L., 2016, Developing and validating climate smart agriculture practices portfolios for smallholder ricewheat systems of Eastern IGP. $4^{\text {th }}$ Int. Agron. Cong. New Delhi, India, 1: 31-32.

\section{How to cite this article:}

Siddagangamma, K. R. 2020. Agronomic Approaches to Improve Cereal Production under Abiotic Stress. Int.J.Curr.Microbiol.App.Sci. 9(02): 2885-2894.

doi: https://doi.org/10.20546/ijcmas.2020.902.328 